\title{
Epidemiological profile of cancer patients from an area with high pesticide use
}

\author{
Perfil epidemiológico de pacientes com câncer de uma área com alto \\ uso de agrotóxico
}

Thaís Bremm Pluth', Lucas Adalberto Geraldi Zanini², lara Denise Endruweit Battisti ${ }^{\mathbf{3}}$, Erikson

Kaszubowski ${ }^{4}$

DOI: 10.1590/0103-1104202012705

\begin{abstract}
Pesticide consumption has increased considerably in the last years. Although pesticides have helped to increase the crops' productivity, they have been associated with the incidence of cancers. The objective of this study was to describe the epidemiological profile of cancer patients living in an area with high use of pesticide. A retrospective cohort design was used to describe cancer cases. Patients were included whenever (i) diagnosed with any type of cancer between 2005 and 2016; (ii) living, at the time of diagnosis, in one of the 69 Brazilian cities studied; and (iii) aged 12 years old or over. A multilevel regression model was used to model the cancer morbidity coefficient. A total of 10,640 cancer patients were studied. Cancer morbidity coefficients increased with age and were significantly higher among people residing in rural areas than among those living in urban areas ( $\mathrm{p}$-value $<0.0001$ ). In both urban and rural areas, males showed significantly higher cancer morbidity coefficients than females. This study suggests that higher cancer incidence is related to factors of rural life, which can include pesticide exposure since the studied area is known for its agriculture based economy and high pesticide use.
\end{abstract}

KEYWORDS Neoplasms. Agrochemicals. Rural population. Morbidity. Environmental health.

1 Universidade Federal da Fronteira Sul (UFFS) Cerro Largo (RS), Brasil. thaisbremm@hotmail.com

2 Hospital de Caridade de ljuí ( $\mathrm{HCl}$ ) - ljuí (RS), Brasil.

3 Universidade Federal da Fronteira Sul (UFFS) -

Cerro Largo (RS), Brasil.

4 Universidade Federal de Santa Catarina (UFSC) -

Florianópolis (SC), Brasil.

RESUMO O consumo de agrotóxicos aumentou consideravelmente nos últimos anos. Embora os agrotóxicos tenham ajudado a aumentar a produtividade das culturas, também têm sido associados ao câncer. O objetivo deste estudo foi descrever o perfil epidemiológico de pacientes oncológicos localizados em uma área com alto uso de agrotóxicos. Empregou-se coorte retrospectiva para descrever os casos de câncer. Incluíram-se pacientes diagnosticados com algum tipo de câncer entre 2005 e 2016, residindo, no momento do diagnóstico, em uma das 69 cidades brasileiras estudadas e com idade igual ou superior a 12 anos. Utilizou-se regressão multinível para modelar o coeficiente de morbidade por câncer. Estudaram-se 10.640 pacientes com câncer. Os coeficientes de morbidade por câncer aumentaram com a idade e foram significativamente maiores entre as pessoas que residiam em áreas rurais, quando comparadas com as residentes das áreas urbanas ( $p<0,0001)$. Em ambas as áreas, os homens apresentaram coeficientes de morbidade por câncer significativamente maiores do que as mulheres. Este estudo sugere que a maior incidência de câncer está relacionada a fatores da vida rural, como a exposição à agrotóxicos, visto que a área estudada é conhecida por sua economia baseada na agricultura e no elevado uso de agrotóxicos.

PALAVRAS-CHAVE Neoplasias. Agroquímicos. População rural. Morbidade. Saúde ambiental. 


\section{Introduction}

Pesticide consumption has increased drastically in Brazil in the last few years. While in 2005 the consumption per planted area was $3.2 \mathrm{~kg} \mathrm{ha}^{-1}$, in 2014 this proportion more than doubled $(6.7 \mathrm{~kg}$ $\left.\mathrm{ha}^{-1}\right)^{1}$. Pesticides have been used mainly in monoculture crops. In 2015, Brazil planted 71.2 million hectares of crops; among the 21 crops analyzed, soybean predominated, representing $42 \%$ of the total planted area in the country, followed by corn, $21 \%$, and sugar cane, $13 \%$. Together, these three crops not only accounted for $76 \%$ of the total planted area in Brazil but also most demanded the use of pesticides, which corresponded to $82 \%$ of all the country's consumption in $2015^{2}$.

The state of Rio Grande do Sul (RS) was the third largest pesticide consumer in Brazil in $2018^{3}$. According to the agricultural census carried out in $2017^{4}$, RS had the largest number of agricultural establishments using pesticides (256,213), equivalent to $15.2 \%$ of Brazil's total number. The percentage of agricultural establishments using pesticides in RS is much higher than the country's as a whole. In Brazil, $33.1 \%$ of the agricultural establishments use pesticides while in RS 70.2\% do so ${ }^{4}$. The northwest region of RS was found to have the largest pesticide consumption of the state ${ }^{5}$.

Although pesticides have helped to increase the crops' productivity, they have been associated with the incidence of several chronic diseases, such as cancers ${ }^{6}$. An integrative literature review found that the relation of pesticides to certain types of cancers, i.e., prostate, Non-Hodgkin lymphoma, leukemia, multiple myeloma, bladder, and colon, is well established, while further investigation is needed to understand the relation between pesticide and neoplasm of testis, breast, esophagus, kidney, thyroid, lip, head, neck, and bone?.

There have been many studies investigating the association of pesticides and cancer in North America and Europe. Results from the Agricultural Health Study, a prospective cohort of licensed pesticide applicators from the United States, have greatly expanded the scientific knowledge on this topic ${ }^{6,8-10}$. In Canada, the main contributions come from the Canadian census health and environment cohort ${ }^{\mathbf{1 1}}$. In Europe, results from the Pesticide Users Health Study ${ }^{\mathbf{1 2}}$ from Great Britain and the Agriculture and Cancer (Agrican) cohort study ${ }^{\mathbf{1 3}}$ from France have also found significant associations between pesticides and cancers.

Many of those pesticides associated with cancer are no longer approved in the European Union, but they are still approved and applied in Brazil7. The aim of this study was to describe the epidemiological profile of all types of cancer cases found in an area of the state of RS showing high use of pesticide. Our hypothesis was that the Cancer Morbidity Coefficient (CMC) was higher in rural areas, due to people's direct pesticide exposure, than in urban areas, where people are not directly exposed to pesticide.

\section{Material and methods}

\section{Study design}

Quantitative and descriptive approaches were used. A retrospective cohort design was used to describe cancer cases.

\section{Setting}

The study was carried out with cancer patients diagnosed between 2005 and 2016, who were treated at the High Complexity Oncological Center (Centro de Alta Complexidade em Oncologia - Cacon) located at the Charity Hospital of Ijuí (Hospital de Caridade de Ijuí - HCI), Ijuí, RS, Brazil. This center was chosen for being the only specialized center of its kind in the northwest region of RS state. Data was collected between October and December 2017.

\section{Participants}

People and cities were included in the research whenever Cacon-Ijuí was their only 
oncological center reference for: clinical oncology, oncological surgery, chemotherapy, radiotherapy, hematology, and brachytherapy, following Resolution 108/2013 ${ }^{14}$ issued by the RS Health Secretary. A total of 69 cities met this criterion (picture 1). They made part of the regional health coordination (Coordenadoria Regional de Saúde - CRS) numbers 12 (24 cities), 15 (14 cities), 17 (20 cities), and 19 (11 cities). These 69 cities corresponded to a population of 565,303 people ${ }^{15}$, also being known for their agriculture based economy, in which soybeans, corn, and wheat were the three main crops ${ }^{16}$.

All patients of both gender were included in this study whenever (i) diagnosed with cancer between 2005 and 2016; (ii) living, at the time of diagnosis, in one of the 69 cities included in this study; and (iii) aged 12 years old or over, since pediatric cancer patients are referred to other establishments. Only the first diagnosis of each patient was analyzed to ensure that each cancer patient was included only once in the dataset.

Picture 1. Location of the 69 cities included in this study that have the High Complexity Oncological Center of ljuí as their only reference on oncological center

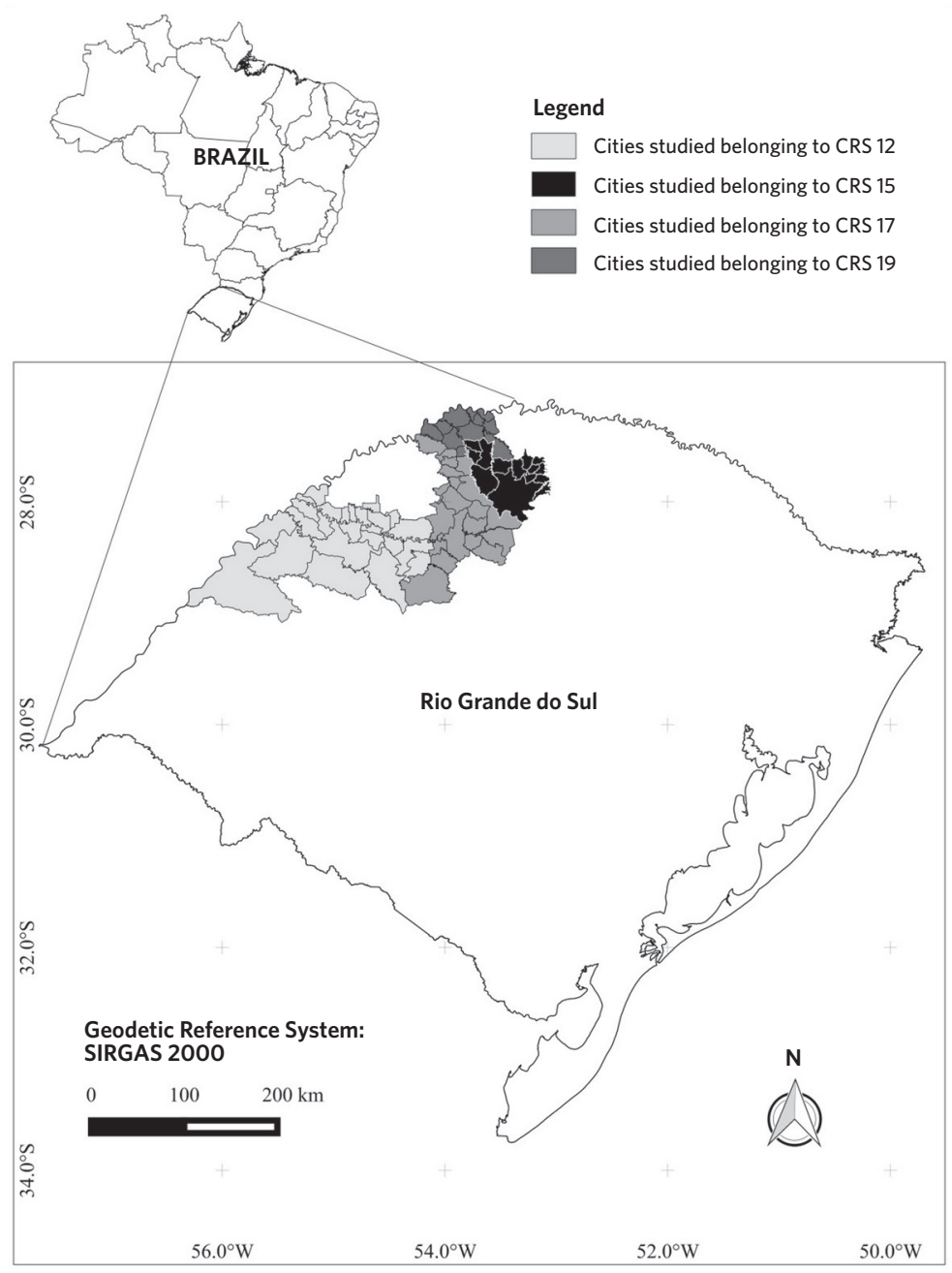




\section{Variables}

The predictive variables were: gender, age, type of cancer, and residence. The outcome was average CMC per year. The CMCs were aggregated using groups of cancer codes, following the International Classification of Diseases and Related Health Problems 10th Revision (ICD-10).

Since 2010 is the last year with available census data, and considering that the population between 2005 and 2016 did not differ greatly from that of 2010, the CMC was calculated assuming the population of each city to be constant over the twelve years studied. Years after 2016 were not included in this study because the 2020 census was considered more appropriate for calculations, but it was not available at the time this research was conducted.

For each subset examined, the population considered was the number of inhabitants specific to that subset. Thus, the average CMC per year $i$ was calculated for different subsets $k$, per place $j$, and normalized for $1,000,000$ inhabitants $(n=6)$ according to Equation 1. The subsets consisted of gender and place of residence as well as their interactions. For modeling, CMCs were evaluated at the city level, but for the descriptive analysis, cities were combined to evaluate regions.

$$
C M C_{j, k}=\frac{\sum_{i=2005}^{2016} \text { Cancer }_{\text {cases } i, j, k}}{\text { Population }_{2010, j, k}} \times \frac{10^{n}}{12}
$$

For the multilevel regression model, the predictive variables were: gender and place of residence on the first level, and linear tendency for crop production and cultivated area on the second level.

\section{Data sources}

A dataset, in the form of a spreadsheet, containing medical records of patients was obtained directly from the information technology department of the HCI. The spreadsheet contained information regarding gender, age, address of residence, type of cancer, date of diagnosis, date of treatment, occupation, and the patient identification code. The code was necessary to identify patients with several diagnosis and/or treatments so to remove duplicates. The address of residence was used to classify patients into rural or urban areas. For those patients whose address was not sufficient to fulfill that classification, maps from google maps were used to help classifying the address. When neither the address provided by the patients nor the maps were sufficient to classify their residence into rural or urban areas, those patients were excluded from the residence analysis, totaling 20 patients.

Population data was obtained from the Brazilian Institute of Geography and Statistics (Instituto Brasileiro de Geografia e Estatística - IBGE) ${ }^{15}$ for each city studied, for the year 2010, which is the most recent census year.

Crop production data on soybean, corn, and wheat, as well as crop planted areas, were collected from IBGE ${ }^{\mathbf{1 7}}$ for each city, for all available periods, i.e., 1974-2016 and 1988-2016, respectively.

\section{Bias}

Since all cancer patients that met the research criteria were included, there was no source of bias during the selection of participants. Additionally, two independent researchers classified the patients as for their residence into either rural or urban areas to minimize a potential source of bias.

\section{Ethics}

This study was approved by the Research Ethics Committee of the Federal University of Fronteira Sul, following document number 2,319,404. The Free and Clarified Consent Form was waived for this work as there was no direct contact with the patients. 


\section{Statistical analysis and data modeling}

For statistical analysis, R software version 3.5.2 was used considering a significance level of $\alpha=0.05$. Qualitative variables were described by absolute and relative frequencies, and the quantitative variable was described by measures of position and variability.

The outcome variable, CMC, was modeled using a multilevel regression model. The CMC was stratified into four groups of interest, according to gender and the place of residency: rural women, urban women, rural men, and urban men. The linear trend of crop production, i.e., total corn, soybean and wheat, and the linear trend of the cultivated area were estimated. In order to evaluate the possible relation between the $\mathrm{CMC}$, the crop production and the cultivated area, the slope coefficients for time for each of these variables were used as predictors in the CMC model. As the information on each group of interest is given per city, the cities were included as random effects on the intercepts of the model. The hypotheses were tested using six linear contrasts while the $\mathrm{p}$-values were corrected for multiple comparisons.

\section{Results}

Based on the dataset obtained from CaconIjuí, 10,640 cancer patients met the research criteria and were therefore analyzed in this study. Of these, 5,497 (51.7\%) patients were males and 5,143 (48.3\%) were females. Most cancer patients (45.0\%) were from the CRS-17, followed by CRS-12 (35.4\%), CRS-19 (11.4\%), and CRS-15 (8.2\%), and that distribution did not vary with gender. Most of the males were farmers $(44.4 \%)$, while only $20.2 \%$ of the females worked in this occupation.

\section{Cancer morbidity coefficient according to age}

The minimum age of a patient diagnosed with cancer was 12.3 years old and the maximum achieved 104.6 years old with a mean age of $61.2 \pm 14.1$ years old.

The cancer morbidity coefficient for males (table 1) and females (table 2) increased with age up to 79 years old and then decreased. For males aged between 12 and 19, 30 and 39, and 60 or above, neoplasms of male genital organs (C60-63) showed the highest CMC. All 76 cases within the C60-63 group for those males between 12 and 39 years old accounted for testicular cancer (C62). Prostate cancer was the most common type of cancer within the C60-63 group in males aged 60 years old or over, equivalent to $99.4 \%$ of the cases within in that age range and cancer group.

Lymphohematopoietic cancers (C81-C96) exhibited the highest CMC among males between 20 and 29 years old, and were the second highest among those between 12 and 19 years old. That group also appeared equal to the C60-63 group within the range 30 to 39 years old.

For males between 40 and 59 years old, cancer of digestive organs (C15-C26) showed the highest $\mathrm{CMC}$. The most common cancer type arising from this group and age range was the esophageal one, accounting for 153 cases $(30.5 \%)$, followed by colon (28.3\%), and rectal (16.0\%) ones. In contrast, among females from the same age range, the colon cancer equated to $40.0 \%$, while esophagus cancer responded for only $13.5 \%$.

For women between 12 and 19 years old, lymphohematopoietic cancers exhibited the highest CMC. Cancer of female genital organs (C51-58) was the most significant within the range 20 to 29 years old, among which cervix uteri was the most frequent type (76.9\%). For the age of 30 years old and above, breast was the most frequent type of neoplasm among females, showing the highest CMC occurrence between 60 and 69 years old. 
Table 1. Average cancer cases and cancer morbidity coefficient, per year, per 1,000,000 males, per age range, treated at Cacon-ljuí, from 2005 to 2016

\begin{tabular}{|c|c|c|c|c|c|c|c|c|c|c|c|c|c|c|c|c|}
\hline \multirow[b]{2}{*}{ ICD-10 group ${ }^{a}$} & \multicolumn{2}{|c|}{$12-19$ years old } & \multicolumn{2}{|c|}{ 20-29 years old } & \multicolumn{2}{|c|}{ 30-39 years old } & \multicolumn{2}{|c|}{$40-49$ years old } & \multicolumn{2}{|c|}{$50-59$ years old } & \multicolumn{2}{|c|}{$60-69$ years old } & \multicolumn{2}{|c|}{ 70-79 years old } & \multicolumn{2}{|c|}{$\geq 80$ years old } \\
\hline & Cases & CMC & Cases & CMC & Cases & $\mathrm{CMC}$ & Cases & CMC & Cases & $\mathrm{CMC}$ & Cases & CMC & Cases & CMC & Cases & CMC \\
\hline $\mathrm{COO}-\mathrm{C} 14^{\mathrm{b}}$ & 0 & 0.0 & 2 & 3.3 & 12 & 22.1 & 73 & 128.6 & 150 & 302.9 & 106 & 325.6 & 45 & 261.3 & 14 & 213.9 \\
\hline C30-C39d & 0 & 0.0 & 1 & 1.7 & 6 & 11.0 & 33 & 58.1 & 157 & 317.0 & 233 & 715.7 & 176 & $1,022.1$ & 35 & 534.8 \\
\hline C40-C41e & 2 & 3.6 & 1 & 1.7 & 0 & 0.0 & 0 & 0.0 & 1 & 2.0 & 3 & 9.2 & 1 & 5.8 & 0 & 0.0 \\
\hline $\mathrm{C} 50-\mathrm{C} 50^{\mathrm{h}}$ & 0 & 0.0 & 1 & 1.7 & 0 & 0.0 & 1 & 1.8 & 4 & 8.1 & 7 & 21.5 & 7 & 40.7 & 2 & 30.6 \\
\hline C60-C63i & 10 & 18.1 & 31 & 51.7 & 35 & 64.4 & 27 & 47.6 & 207 & 418.0 & 662 & $2,033.5$ & 724 & $4,204.7$ & 233 & $3,560.1$ \\
\hline C64-C68j & 0 & 0.0 & 1 & 1.7 & 2 & 3.7 & 12 & 21.1 & 39 & 78.8 & 72 & 221.2 & 56 & 325.2 & 17 & 259.7 \\
\hline $\mathrm{C} 69-\mathrm{C} 72^{\mathrm{k}}$ & 5 & 9.0 & 6 & 10.0 & 21 & 38.6 & 18 & 31.7 & 28 & 56.5 & 20 & 61.4 & 22 & 127.8 & 2 & 30.6 \\
\hline D37-D48 & 2 & 3.6 & 1 & 1.7 & 1 & 1.8 & 8 & 14.1 & 10 & 20.2 & 12 & 36.9 & 11 & 63.9 & 5 & 76.4 \\
\hline TOTAL & 35 & 63.2 & 97 & 161.9 & 156 & 286.9 & 410 & 722.2 & 1,129 & $2,279.8$ & 1,741 & $5,347.9$ & 1,484 & $8,618.5$ & 445 & $6,799.3$ \\
\hline
\end{tabular}

Source: Prepared by the authors based on the cancer data from Cacon-ljuí and population data from IBGE15.

Note: Results in bold indicate the highest cancer morbidity coefficient (CMC) in each age group. CMCs are based on the 2010 IBGE' census population.

according to the International Classification of Diseases and Related Health Problems-10th Revision

bMalignant neoplasms of lip, oral cavity and pharynx

cMalignant neoplasms of digestive organs

dMalignant neoplasms of respiratory and intrathoracic organs

eMalignant neoplasms of bone and articular cartilage

'Melanoma and other malignant neoplasms of skin

sMalignant neoplasms of mesothelial and soft tissue

hMalignant neoplasms of breast

Malignant neoplasms of male genital organs

iMalignant neoplasms of urinary tract

kMalignant neoplasms of eye, brain and other parts of central nervous system.

Malignant neoplasms of thyroid and other endocrine glands

mMalignant neoplasms of ill-defined, other secondary and unspecified sites

nMalignant neoplasms of lymphoid, hematopoietic and related tissue

- Neoplasms of uncertain behavior, polycythemia vera and myelodysplastic syndromes.

Table 2. Average cancer cases and cancer morbidity coefficient, per year, per 1,000,000 females, per age range, treated at Cacon-ljuí from 2005 to 2016

\begin{tabular}{|c|c|c|c|c|c|c|c|c|c|c|c|c|c|c|c|c|}
\hline \multirow[b]{2}{*}{ ICD-10 group ${ }^{a}$} & \multicolumn{2}{|c|}{ 12-19 years old } & \multicolumn{2}{|c|}{ 20-29 years old } & \multicolumn{2}{|c|}{ 30-39 years old } & \multicolumn{2}{|c|}{$40-49$ years old } & \multicolumn{2}{|c|}{$50-59$ years old } & \multicolumn{2}{|c|}{$60-69$ years old } & \multicolumn{2}{|c|}{ 70-79 years old } & \multicolumn{2}{|c|}{$\geq 80$ years old } \\
\hline & Cases & CMC & Cases & CMC & Cases & CMC & Cases & CMC & Cases & CMC & Cases & CMC & Cases & CMC & Cases & CMC \\
\hline $\mathrm{COO}-\mathrm{C} 14^{\mathrm{b}}$ & 0 & 0.0 & 2 & 3.4 & 4 & 7.1 & 8 & 13.5 & 25 & 48.6 & 13 & 37.1 & 17 & 80.3 & 7 & 64.5 \\
\hline $\mathrm{C} 15-\mathrm{C} 26^{\mathrm{C}}$ & 2 & 3.8 & 9 & 15.2 & 28 & 49.8 & 88 & 148.9 & 200 & 388.9 & 227 & 648.3 & 234 & $1,105.8$ & 78 & 718.8 \\
\hline C30-C39d & 0 & 0.0 & 4 & 6.7 & 9 & 16.0 & 27 & 45.7 & 69 & 134.2 & 113 & 322.7 & 64 & 302.4 & 9 & 82.9 \\
\hline C40-C41e & 2 & 3.8 & 0 & 0.0 & 0 & 0.0 & 3 & 5.1 & 0 & 0.0 & 0 & 0.0 & 3 & 14.2 & 1 & 9.2 \\
\hline $\mathrm{C} 43-\mathrm{C} 44^{\mathrm{f}}$ & 2 & 3.8 & 6 & 10.1 & 13 & 23.1 & 29 & 49.1 & 39 & 75.8 & 57 & 162.8 & 45 & 212.7 & 28 & 258.0 \\
\hline C45-C49g & 1 & 1.9 & 5 & 8.4 & 7 & 12.5 & 13 & 22.0 & 9 & 17.5 & 10 & 28.6 & 4 & 18.9 & 5 & 46.1 \\
\hline $\mathrm{C} 50-\mathrm{C} 5 \mathrm{O}^{\mathrm{h}}$ & 0 & 0.0 & 28 & 47.2 & 158 & 281.3 & 528 & 893.4 & 585 & 1,137.5 & 477 & $1,362.4$ & 267 & $1,261.8$ & 100 & 921.5 \\
\hline C60-C63i & 8 & 15.1 & 39 & 65.8 & 119 & 211.8 & 174 & 294.4 & 200 & 388.9 & 201 & 574.1 & 138 & 652.1 & 45 & 414.7 \\
\hline C64-C68 & 0 & 0.0 & 1 & 1.7 & 2 & 3.6 & 5 & 8.5 & 20 & 38.9 & 23 & 65.7 & 18 & 85.1 & 7 & 64.5 \\
\hline
\end{tabular}


Table 2. (cont.)

\begin{tabular}{|c|c|c|c|c|c|c|c|c|c|c|c|c|c|c|c|c|}
\hline \multirow[b]{2}{*}{ ICD-10 group ${ }^{a}$} & \multicolumn{2}{|c|}{$12-19$ years old } & \multicolumn{2}{|c|}{ 20-29 years old } & \multicolumn{2}{|c|}{$30-39$ years old } & \multicolumn{2}{|c|}{$40-49$ years old } & \multicolumn{2}{|c|}{$50-59$ years old } & \multicolumn{2}{|c|}{$60-69$ years old } & \multicolumn{2}{|c|}{$70-79$ years old } & \multicolumn{2}{|c|}{$\geq 80$ years old } \\
\hline & Cases & CMC & Cases & CMC & Cases & CMC & Cases & CMC & Cases & CMC & Cases & CMC & Cases & CMC & Cases & CMC \\
\hline $\mathrm{C} 69-\mathrm{C} 72^{\mathrm{k}}$ & 5 & 9.4 & 6 & 10.1 & 8 & 14.2 & 13 & 22.0 & 19 & 36.9 & 12 & 34.3 & 7 & 33.1 & 1 & 9.2 \\
\hline $\mathrm{C} 73-\mathrm{C} 75^{\prime}$ & 0 & 0.0 & 0 & 0.0 & 0 & 0.0 & 1 & 1.7 & 2 & 3.9 & 4 & 11.4 & 1 & 4.7 & 0 & 0.0 \\
\hline $\mathrm{C} 76-\mathrm{C} 80^{\mathrm{m}}$ & 0 & 0.0 & 2 & 3.4 & 2 & 3.6 & 11 & 18.6 & 17 & 33.1 & 27 & 77.1 & 26 & 122.9 & 4 & 36.9 \\
\hline C81-C96n & 12 & 22.6 & 25 & 42.2 & 15 & 26.7 & 18 & 30.5 & 61 & 118.6 & 72 & 205.6 & 52 & 245.7 & 15 & 138.2 \\
\hline D37-D48응 & 1 & 1.9 & 1 & 1.7 & 3 & 5.3 & 2 & 3.4 & 5 & 9.7 & 15 & 42.8 & 14 & 66.2 & 2 & 18.4 \\
\hline TOTAL & 33 & 62.2 & 128 & 215.9 & 368 & 655.1 & 920 & $1,556.7$ & 1,251 & $2,432.5$ & 1,251 & $3,573.0$ & 890 & $4,205.9$ & 302 & $2,783.0$ \\
\hline
\end{tabular}

Source: Prepared by the authors based on the cancer data from Cacon-ljuí and population data from IBGE15.

Note: Results in bold indicate the highest Cancer Morbidity Coefficient (CMC) in each age group. CMCs are based on the 2010 IBGE' census population.

aAccording to the International Classification of Diseases and Related Health Problems-10th Revision; bmalignant neoplasms of lip, oral cavity and pharynx; cmalignant neoplasms of digestive organs; dmalignant neoplasms of respiratory and intrathoracic organs; emalignant neoplasms of bone and articular cartilage; ${ }^{f}$ melanoma and other malignant neoplasms of skin; gmalignant neoplasms of mesothelial and soft tissue; hmalignant neoplasms of breast; imalignant neoplasms of male genital organs; imalignant neoplasms of urinary tract; kmalignant neoplasms of eye, brain and other parts of central nervous system; Imalignant neoplasms of thyroid and other endocrine glands; mmalignant neoplasms of ill-defined and other secondary and unspecified sites; ${ }^{n}$ malignant neoplasms of lymphoid, hematopoietic and related tissue; oneoplasms of uncertain behavior, polycythemia vera and myelodysplastic syndromes.

\section{Cancer cases according to gender}

Among all females studied in this research, the top ten most frequent cancer types equated to $81.5 \%$ of all cases, split among breast (41.7\%), cervix uteri (9.9\%), colon (6.4\%), bronchus and lung (5.2\%), corpus uteri (4.0\%), rectum (3.6\%), ovary (3.4\%), esophagus ( $2.9 \%)$, melanoma of skin (2.4\%), and pancreas (2.0\%).

Among all males, the top ten most frequent cancer types were prostate (33.1\%), bronchus and lungs (9.2\%), colon (6.8\%), esophagus (6.4\%), rectum (4.4\%), skin non-melanoma (2.9\%), stomach (2.9\%), oropharynx (2.8\%), bladder (2.6\%), and skin melanoma (2.5\%). Together, those top ten most common cancer types were equivalent to $73.6 \%$ of all cases among males.

\section{Cancer morbidity coefficient according to residence during diagnosis}

The CMC was higher among males living in rural areas than those living in urban areas for all cancer groups, except to thyroid and other endocrine glands, which had only a few cases diagnosed (table 3).

When the analysis was carried out focusing on cancer types instead of cancer groups, the same pattern was observed. The CMC was higher among males residing in rural areas than among males residing in urban areas for all the ten most common neoplasms. Prostate cancer was the most common cancer diagnosed among males living in both urban and rural areas. Each year, out of 1,000,000 males diagnosed with prostate cancer, 667 were expected to reside in rural areas, while 494 were expected to live in urban ones, resulting in a $35.0 \%$ higher rate.

As for females, the CMC was higher among those residing in rural areas than urban areas for eight out of 14 cancer groups (table 4). Breast cancer exhibited the highest CMC among females living in both urban and rural areas, being the breast CMC higher in urban females than in rural ones. 
Table 3. Average cancer morbidity coefficient, per year, per 1,000,000 males, according to cancer groups among males residing in rural and urban areas, age $\geq 12$ years, treated at Cacon-ljuí, between 2005 and 2016

\begin{tabular}{|c|c|c|c|c|c|c|}
\hline \multirow[b]{2}{*}{ Cancer group ${ }^{a}$} & \multicolumn{3}{|c|}{ Urban } & \multicolumn{3}{|c|}{ Rural } \\
\hline & Cases $(3,445)$ & $\%$ & CMCp & Cases $(2,038)$ & $\%$ & $\mathrm{CMCp}^{\mathrm{p}}$ \\
\hline C60-C63b & 1,206 & 35.0 & 527.9 & 721 & 35.4 & 694.3 \\
\hline $\mathrm{C} 15-\mathrm{C} 26^{\mathrm{c}}$ & 802 & 23.3 & 351.1 & 491 & 24.1 & 472.8 \\
\hline C30-C39d & 416 & 12.1 & 182.1 & 222 & 10.9 & 213.8 \\
\hline $\mathrm{COO}-\mathrm{C} 14 \mathrm{e}$ & 267 & 7.8 & 116.9 & 134 & 6.6 & 129.0 \\
\hline C81-C96f & 229 & 6.6 & 100.2 & 139 & 6.8 & 133.9 \\
\hline C43-C448 & 178 & 5.2 & 77.9 & 117 & 5.7 & 112.7 \\
\hline C64-C68h & 131 & 3.8 & 57.3 & 68 & 3.3 & 65.5 \\
\hline C69-C72i & 77 & 2.2 & 33.7 & 45 & 2.2 & 43.3 \\
\hline C76-C8Oi & 58 & 1.7 & 25.4 & 42 & 2.1 & 40.4 \\
\hline D37-D48k & 30 & 0.9 & 13.1 & 20 & 1.0 & 19.3 \\
\hline C45-C49! & 29 & 0.8 & 12.7 & 25 & 1.2 & 24.1 \\
\hline C50-C50m & 13 & 0.4 & 5.7 & 8 & 0.4 & 7.7 \\
\hline C73-C75n & 6 & 0.2 & 2.6 & 1 & 0.0 & 1.0 \\
\hline $\mathrm{C} 40-\mathrm{C} 41^{\circ}$ & 3 & 0.1 & 1.3 & 5 & 0.2 & 4.8 \\
\hline
\end{tabular}

Source: Prepared by the authors based on the cancer data from Cacon-Ijuí and population data from IBGE15.

Note: A total of twenty patients were excluded from this analysis as their residences could not be classified into either rural or urban ones. according to the International Classification of Diseases and Related Health Problems-10th Revision; bmalignant neoplasms of male genital organs; ' cmalignant neoplasms of digestive organs; dmalignant neoplasms of respiratory and intrathoracic organs; emalignant neoplasms of lip, oral cavity and pharynx; ' malignant neoplasms of lymphoid, hematopoietic and related tissue; gmelanoma and other malignant neoplasms of skin; ${ }^{\prime}$ malignant neoplasms of urinary tract; imalignant neoplasms of ill-defined and other secondary and unspecified sites; imalignant neoplasms of eye, brain and other parts of central nervous system; kmalignant neoplasms of mesothelial and soft tissue; Ineoplasms of uncertain behavior, polycythemia vera and myelodysplastic syndromes; mmalignant neoplasms of breast; nmalignant neoplasms of thyroid and other endocrine glands; 'malignant neoplasms of bone and articular cartilage; paverage cancer morbidity coefficient based on the 2010 IBGE'census population.

Table 4. Average cancer morbidity coefficient, per year, per 1,000,000 females, according to cancer groups among females residing in rural and urban areas, age $\geq 12$ years, treated at Cacon-ljuí, between 2005 and 2016

\begin{tabular}{|c|c|c|c|c|c|c|}
\hline \multirow[b]{2}{*}{ Cancer group ${ }^{a}$} & \multicolumn{3}{|c|}{ Urban } & \multicolumn{3}{|c|}{ Rural } \\
\hline & Cases $(3,645)$ & $\%$ & $\mathrm{CMCp}$ & Cases $(1,492)$ & $\%$ & $\mathrm{CMC}^{\mathrm{p}}$ \\
\hline $\mathrm{C} 50-\mathrm{C} 5 \mathrm{O}^{\mathrm{b}}$ & 1,561 & 42.8 & 623.8 & 581 & 38.9 & 606.2 \\
\hline $\mathrm{C} 51-\mathrm{C} 58^{\mathrm{c}}$ & 667 & 18.3 & 266.5 & 256 & 17.2 & 267.1 \\
\hline $\mathrm{C} 15-\mathrm{C} 26^{\mathrm{d}}$ & 588 & 16.1 & 235.0 & 276 & 18.5 & 288.0 \\
\hline C30-C39e & 222 & 6.1 & 88.7 & 72 & 4.8 & 75.1 \\
\hline C81-C96f & 173 & 4.7 & 69.1 & 97 & 6.5 & 101.2 \\
\hline C43-C44g & 130 & 3.6 & 52.0 & 88 & 5.9 & 91.8 \\
\hline $\mathrm{C} 76-\mathrm{C} 8 \mathrm{O}^{\mathrm{h}}$ & 68 & 1.9 & 27.2 & 21 & 1.4 & 21.9 \\
\hline C64-C68 & 61 & 1.7 & 24.4 & 15 & 1.0 & 15.7 \\
\hline $\mathrm{COO}-\mathrm{C} 14 \mathrm{j}$ & 51 & 1.4 & 20.4 & 25 & 1.7 & 26.1 \\
\hline $\mathrm{C} 69-\mathrm{C} 72^{\mathrm{k}}$ & 44 & 1.2 & 17.6 & 27 & 1.8 & 28.2 \\
\hline C45-C49' & 35 & 1.0 & 14.0 & 19 & 1.3 & 19.8 \\
\hline
\end{tabular}


Table 4. (cont.)

\begin{tabular}{lrrrrrr}
\hline & \multicolumn{3}{c}{ Urban } & \multicolumn{3}{c}{ Rural } \\
\cline { 2 - 7 } Cancer group $^{a}$ & Cases (3,645) & \% & CMCp & Cases $(\mathbf{1 , 4 9 2 )}$ & $\%$ & CMC $^{\text {p }}$ \\
\hline D37-D48m & 32 & 0.9 & 12.8 & 11 & 0.7 & 11.5 \\
C73-C75n & 7 & 0.2 & 2.8 & 1 & 0.1 & 1.0 \\
C40-C470 & 6 & 0.2 & 2.4 & 3 & 0.2 & 3.1 \\
\hline
\end{tabular}

Source: Prepared by the authors based on the cancer data from Cacon-ljuí and population data from IBGE15.

Note: A total of twenty patients were excluded from this analysis as their residences could not be classified into either rural or urban ones. aAccording to the International Classification of Diseases and Related Health Problems-10th Revision; bmalignant neoplasms of male genital organs; ' cmalignant neoplasms of digestive organs; dmalignant neoplasms of respiratory and intrathoracic organs; emalignant neoplasms of lip, oral cavity and pharynx; fmalignant neoplasms of lymphoid, hematopoietic and related tissue; gmelanoma and other malignant neoplasms of skin; ' hmalignant neoplasms of urinary tract; imalignant neoplasms of ill-defined and other secondary and unspecified sites; imalignant neoplasms of eye, brain and other parts of central nervous system; kmalignant neoplasms of mesothelial and soft tissue; 'neoplasms of uncertain behavior, polycythemia vera and myelodysplastic syndromes; ${ }^{m}$ malignant neoplasms of breast; "malignant neoplasms of thyroid and other endocrine glands; omalignant neoplasms of bone and articular cartilage; paverage cancer morbidity coefficient based on the 2010 IBGE'census population.

\section{Modeling}

The complete model embracing all predictive variables was considered and evaluated at the beginning. Then, the second level predictors were removed, one at a time, and evaluated as for their significance to the model. The only predictor that improved the model fit was the group of interest, therefore being the only one kept in the final model.

The main marginal effect for place of residence indicated higher CMC for residents of rural areas $(\beta=205.6, \mathrm{p}$-value $<0.0001)$. Gender also showed a significant main marginal effect because males exhibited higher CMC than females $(\beta=313.4$, $p$-value $<0.0001)$.

Paired comparisons between different groups from the subsets of interest were carried out. When considering those living in rural areas, $\mathrm{CMC}$ was higher for males than for females $(\Delta=371$, p-value $<0.0001)$. CMC was also higher for males than for females living in urban areas, although of a smaller difference $(\Delta$ $=256$, $\mathrm{p}$-value $=0.015$ ). The difference between males and females did not vary significantly between rural and urban areas $(\Delta=115$, p-value $=0.35$ ), which is consistent with the lack of an interaction effect between gender of patients and place of residence. Nonetheless, if solely males are taken into consideration, those living in rural areas showed higher CMC $(\Delta=263$, $\mathrm{p}$-value $=0.01)$. Among women, the difference between those living in rural areas and in urban ones was positive, but not significant $(\Delta=149, \mathrm{p}$-value $=0.30)$. The highest $\mathrm{CMC}$ difference was achieved between rural males and urban females $(\Delta=519$, p-value $<0.0001)$.

\section{Discussion}

The frequencies of patients according to the CRS can be explained by the proximity of the cities to the Cacon. Ijuí is located in the CRS-13 and was the city exhibiting the highest number of patients, or $19.0 \%$ of the total.

In our study, there were more male cancer patients working in farm-related jobs than female ones. Lemarchand et al. ${ }^{13}$ found prostate, lip, and overall cancer risks significantly higher in male farm workers. Kachuri et al."1 observed increased hazard ratios among male agricultural workers for non-Hodgkin lymphoma, prostate, melanoma, and lip cancer. In our study, unfortunately, the coefficient of morbidity as for occupation could not be calculated as Brazil does not provide population data broken into occupation per city. 


\section{Cancer morbidity coefficient according to age}

For males between 20 and 44 years old, testicular cancer incidence found in this study was similar to what was reported by the National Cancer Institute ${ }^{18}$, which estimated that $50.5 \%$ of new testicular cancer cases occurs in the range 20 to 34 years old and $23.1 \%$ occurs between 35 and 44 years old. A statistically significant excess of incidence of testicular cancer among British agricultural pesticide users was found by Frost et al.12.

In our study, lymphohematopoietic cancers showed high incidences among males between 20 and 39 years old. Several studies have found significant associations between those cancers in adult males exposed to pesticides. Lynch et al. ${ }^{9}$ observed increased risks for all lymphohematopoietic cancers when exposed to the herbicide butylate. Hohenadel et al. ${ }^{19}$ found that high exposure to insecticide, herbicide, or fungicide was significantly associated to increased risk of non-Hodgkin lymphoma than to people not exposed. Kachuri et al..$^{20}$ showed that captan fungicide and carbaryl insecticide increased multiple myeloma risk.

Among males between 40 and 59 years old, the highest CMC was found for the group of cancer of digestive organs (table 1). For that group and age range, the most frequent cancers arisen in our study were esophageal, colon, and rectal. Esophageal tumors, mainly the epidermoid subtype, are related to alcohol consumption and smoking, especially when combined $^{21}$. However, esophageal squamous cell carcinoma has been shown to be significantly associated with the ingestion of high temperature beverages (above $65^{\circ} \mathrm{C}$ ) ${ }^{\mathbf{2 2}}$. The area studied in this research is particularly distinct from the rest of Brazil for its common consumption of mate, a hot beverage similar to tea that might influence the high rate of esophageal cancer. Although esophageal cancer has not been found to be significantly associated with pesticide exposure ${ }^{23}$, colon and rectal cancer have. A case-control study carried out in Egypt showed that exposure to insecticides or herbicides was associated with increased risk for colorectal cancer ${ }^{\mathbf{2 4}}$.

The high incidence of prostate cancer in males aged 60 or older found in this study is expected worldwide, as prostate cancer is the most common type of cancer among elderly males $^{25}$. A systematic review ${ }^{26}$ involving 32 studies found a positive association between prostate cancer and pesticides or agricultural occupations.

In our study, cancer of cervix uteri was the most frequent type among females between 20 and 29 years old. The main cause of that neoplasm is the Human Papillomavirus ${ }^{27}$, typical in developing countries like Brazil. Since that cancer already has a main risk factor well defined, the relation to pesticides has not been identified. A case-control study conducted in rural areas of Wuhan, China, investigated risk factors for cervical cancer although not finding any relation to insecticides ${ }^{28}$.

The high incidence of breast cancer found in this study among females aged 30 or older was similar to the incidence rates worldwide, since breast cancer was also reported to increase with age, reaching the highest rates between 65 and 70 years old 25 .

\section{Cancer cases according to gender}

Cancer frequencies for females found in this study differ from estimations for Brazil in 2016: breast (28.1\%), intestine (8.6\%), lungs (5.3\%), and stomach (3.7\%). They also differ for females in the state of Rio Grande do Sul: breast (20.0\%), colorectal (6.4\%), trachea, bronchus, and lung $(6.1 \%)^{29}$. As can be seen, female breast cancer incidence in the region studied (41.7\%) is much higher than the estimations for the state $(20.0 \%)$ and the country (28.1\%). A study with spouses of pesticide applicators 8 found that exposure to organophosphate insecticides was associated with an elevated risk of breast cancer.

Cancer frequencies for males found in this study were similar to estimations for males in 
Brazil for 2016, where prostate cancer (28.6\%) also appeared in the first position, followed by lung cancer (8.1\%) ${ }^{29}$.

\section{Cancer morbidity coefficient according to residence during diagnosis}

The CMCs were higher among rural people than to urban people. When comparing the CMCs between males and females, it can be noted that they were much higher for males than for females. In this study, the place of residence, being it rural or urban, was used to estimate the degree of pesticide exposure since the information about the actual exposure could not be obtained.

Godin et al. ${ }^{30}$ observed that only colon and rectum cancer incidence rates were significantly higher among males in Pennsylvania rural counties than those from urban Pennsylvania counties. Among females, only the incidence of skin melanoma was significantly higher in Pennsylvania rural counties than those from urban Pennsylvania counties.

Our results differ from a study carried out in the Republic of Suriname ${ }^{\mathbf{3 1}}$ which showed that both overall cancer incidence rate and incidence rates for most cancer types were higher among those residing in urban areas than those from rural ones.

\section{Modeling}

Inhabitants of rural areas, regardless of gender, exhibited a higher incidence of cancer. Each city showed an average of 205 more cancer cases per year per 1,000,000 inhabitants in rural areas than in urban ones. As for gender itself, males were more affected than females, revealing an average of 313 more cancer cases per year per 1,000,000 inhabitants. The interaction between the predictors place of residence and gender was not significant. The pairwise comparisons between subsets indicated that there was no significant difference between rural and urban females, although that difference was large and significant between males. Rural males showed significantly greater cancer incidence rate than urban males. Each city showed an average of 263 more cancer cases per year per 1,000,000 inhabitants. All those results suggest that rural males were considerably more likely to have cancer, which corroborates the initial hypothesis.

\section{Conclusions}

Results revealed that the cancer incidence rate increased with age and was higher among people residing in rural areas than among those from urban areas. Within both urban and rural areas, males showed higher cancer incidence rate than females. This study suggests that higher cancer incidence rate is related to factors of rural life, which can include pesticide exposure since the studied area is known for its agriculture based economy and high use of pesticide.

\section{Collaborators}

Pluth TB (0000-0002-5851-9476)* contributed to the research conception and design; acquisition, analysis, and data interpretation; and drafting of the manuscript. Zanini LAG (00000002-3849-6211)* assisted in data acquisition and interpretation; and drafting of the manuscript. Battisti IDE (0000-0001-9740-4199)* made the critical review of the content; and assisted in the research conception and design. Kaszubowski E (0000-0001-5481-1755)* assisted in the analysis and interpretation of data; and made the critical review of the content. All authors read and approved the final version of the manuscript. 


\section{References}

1. Brazilian Institute for Geography and Statistics. Tabela 772: comercialização de agrotóxicos e afins, área plantada das principais culturas e comercialização por área plantada [internet]. [n.d.] [accessed 2017 Nov 15]. Available from: https://sidra.ibge.gov.br/tabela/772.

2. Pignati WA, Neri de Souza e Lima FA, Sommerfeld de Lara S, et al. Spatial distribution of pesticide use in Brazil: a strategy for health surveillance. Ciênc. Saúde Colet. 2017; 22:3281-93.

3. Brazilian Institute of the Environment and Renewable Natural Resources. Relatórios de comercialização de agrotóxicos: Boletim 2018 [internet]. 2018 [accessed 2020 Aug 13]. Available from: http://ibama.gov. br/index.php?option=com_content\&view $=$ article $\& \mathrm{i}$ $\mathrm{d}=594 \&$ Itemid $=546$.

4. Brazilian Institute for Geography and Statistics. Censo agropecuário: resultados definitivos 2017. Rio de Janeiro: IBGE; 2019.

5. Pereira JP. Espacialização do uso de agrotóxicos por região de saúde no RS [thesis]. Porto Alegre: Universidade Federal do Rio Grande do Sul; 2014.

6. Weichenthal S, Moase C, Chan P. A review of pesticide exposure and cancer incidence in the Agricultural Health Study Cohort. Ciênc. Saúde Colet. 2012; 17(1):255-70.

7. Pluth TB, Zanini LAG, Battisti IDE. Pesticide exposure and cancer: an integrative literature review. Saúde debate. 2019; 43(122):906-24.

8. Lerro CC, Koutros S, Andreotti G, et al. Organophosphate insecticide use and cancer incidence among spouses of pesticide applicators in the Agricultural Health Study. Occup Environ Med. 2015; (72):736-44.

9. Lynch SM, Mahajan R, Beane Freeman LE, et al. Cancer incidence among pesticide applicators exposed to butylate in the Agricultural Health Study (AHS). Environ Res 2009; (109):860-8.
10. Alavanja MCR, Hofmann JN, Lynch CF, et al. Non-Hodgkin lymphoma risk and insecticide, fungicide and fumigant use in the agricultural health study. PLoS One 2014; (9):1-17.

11. Kachuri L, Harris MA, MacLeod JS, et al. Cancer risks in a population-based study of 70,570 agricultural workers: results from the Canadian census health and Environment cohort (CanCHEC). BMC Cancer 2017; (17):343.

12. Frost G, Brown T, Harding a-H. Mortality and cancer incidence among British agricultural pesticide users. Occup Med (Lond). 2011; (61):303-10.

13. Lemarchand C, Tual S, Levêque-Morlais N, et al. Cancer incidence in the AGRICAN cohort study (20052011). Cancer Epidemiol. 2017; (49):175-85.

14. Rio Grando do Sul. Secretaria Estadual de Saúde. Resolução No 108 de 11 de Abril de 2013. Porto Alegre: Diário Oficial de Porto Alegre. 11 Apr 2013.

15. Brazilian Institute for Geography and Statistics. Contagem da população: tabela 793 - população residente 2010 [internet]. [n.d]. [accessed 2018 Jun 10]. Available from: https://sidra.ibge.gov.br/tabela/793.

16. Fundação de Economia e Estatística. Características da agropecuária do RS 2015 [internet]. 2015 [accessed 2020 Aug 12]. Available from: https://arquivofee. rs.gov.br/sinteseilustrada/caracteristicas-da-agropecuaria-do-rs/.

17. Brazilian Institute for Geography and Statistics. Tabela 1612 - Área plantada, área colhida, quantidade produzida, rendimento médio e valor da produção das lavouras temporárias [internet]. [n.d.] [accessed 2017 Nov 3]. Available from: https://sidra.ibge.gov. br/Tabela/1612.

18. National Cancer Institute. Cancer Stat Facts: Testicular cancer [internet] n.d. [accessed 2018 Dec 30]. Available from: https://seer.cancer.gov/statfacts/html/ testis.html. 
19. Hohenadel K, Harris SA, McLaughlin JR, et al. Exposure to multiple pesticides and risk of non-Hodgkin lymphoma in men from six Canadian provinces. Int J Environ Res Public Health. 2011; (8):2320-30.

20. Kachuri L, Demers PA, Blair A, et al. Multiple pesticide exposures and the risk of multiple myeloma in Canadian men. Int J Cancer. 2013; (133):1846-58.

21. Freedman ND, Abnet CC, Leitzmann MF, et al. Original contribution a prospective study of tobacco, alcohol, and the risk of esophageal and gastric cancer subtypes. Am J Epidemiol 2007; (165):1424-33.

22. Lubin JH, Stefani E, Abnet CC, et al. Maté drinking and esophageal squamous cell carcinoma in South America: pooled results from two large multi-center case-control studies. Canc. Epidemiol Biomarkers Prev. 2014; (23):107-16.

23. Yildirim M, Kaya V, Yildiz M, et al. Esophageal cancer, gastric cancer and the use of pesticides in the southwestern of Turkey. Asian Pacific J Cancer Prev. 2014; (15):2821-3.

24. Lo A-C, Soliman AS, Khaled HM, et al. Lifestyle, occupational, and reproductive factors and risk of colorectal cancer. Dis Colon Rectum. 2010; (53):830-7.

25. Brasil. Instituto Nacional de Câncer. Câncer no Brasil: dados dos registros de base populacional. v. III. Rio de Janeiro: INCA; 2003.
26. Silva JF, Mattos IE, Luz LL, et al. Exposure to pesticides and prostate cancer: systematic review of the literature. Environ Heal. 2016; (31):311-27.

27. Clifford G, Smith J, Plummer M, et al. Human papillomavirus types in invasive cervical cancer worldwide: a meta-analysis. Br J Cancer 2003; (88):63-73.

28. Zhang B, Zhou A-F, Zhu C-C, et al. Risk factors for cervical cancer in rural areas of Wuhan China: a matched case-control study. Asian Pac J Cancer Prev. 2013; (14):7595-600.

29. Instituto Nacional de Cancer José Alencar Gomes da Silva. Estimativa 2016: incidência de câncer no Brasil. Rio de Janeiro: INCA; 2015.

30. Godin S, Lesko S, Lengerich E, et al. Comparisons of cancer incidence and mortality for rural vs. urban Pennsylvania counties, rural appalachian counties, and rural U.S. counties. Cent Rural Pennsylvania. 2014; (2):1-20.

31. Mans DRA, Rijkaard E, Dollart J, et al. Differences between urban and rural areas of the Republic of Suriname in the ethnic and age distribution of cancer a retrospective study from 1980 through 2004. Open Epidemiol J. 2008; (1):30-5.

\footnotetext{
Received on 10/28/2019

Approved on 09/18/2020

Conflict of interests: non-existent
}

Financial support: non-existent 